\title{
Is Confucius a Sinicus Cicero?
}

\section{Introduction}

Confucius Sinarum Philosophus sive Scientia Sinensis (hereafter, Confucius Sinarum) was published by order of Louis XIV in Paris in $1687^{1}$ The praefatio presents a general overview of Chinese scholarship and the views of Jesuits on Chinese thought and philosophy and Confucii vita. In the main text were included Latin translations of Magna Scientia (Ta-Hio, 大學), Medium Sempiternum (Chum-Yum, 中庸) and Ratiocinantium Sermones (Lun-Yu, 論語). In the appendix was added Tabula Chronologica Monarchiae Sinicae. Mencius (孟子) was not translated. ${ }^{2}$ Translations were made in the way of verbum pro verbo: to each Latin term translators gave a number to indicate from which Chinese character it was translated. Translations were made on the basis of cooperative discussions and co-scholarship between Jesuit missionaries and prominent Chinese scholars of the time. The pioneer of this was Michele Ruggieri (羅明堅, 1543-1607), who attempted to publish a Chinese translation in Rome in 1590. However, it failed due to technical problems in printing. His manuscript is preserved now in the Biblioteca Nazionale Centrale 'Vittorio Emanuele II' ('Fondo Gesuitico 1195'). Following him, Matteo Ricci (利瑪竇, 1552-1610) undertook to translate Chinese classical texts into Latin, but his translation did not appear. In 1662, Ignatius da Costa (郭納爵, 1599-1666) and Prospero Intorcetta (殷鐸澤, 1626-1696) succeeded in publishing Magna Scientia (Ta-Hio, 大學) together with Vita Confucii under the title of Sapientia Sinica in Jiangxi (江西) in China. In 1672, Intorcetta published Medium Sempiternum (Chum-Yum, 中庸) as Sinarum Scientia Politico-moralis. ${ }^{3}$ The Vorlage for this was Zhu hi's edition. Intorcetta also used Zhang Colaus' (張居正, 1525-1582) Sa-Seo-Zik-Hae (四書直解) for his interpretation. In 1687, Couplet (1623-1693) finally published Confucius Sinarum, which was a cumulative product of Jesuit missionaries from Ruggieri to Couplet himself compiled over a period of nearly 100 years. More recently, the text was published

1 The full title of it: Confucius Sinarum Philosophus sive Scientia Sinensis Latina exposita, Studio et opera Prosperi Intorcetta, Christiani Herdtrich, Francisici Rougemont, Philippi Couplet, Patrum Societatis (1687), Jussu Ludovici Magni Eximio Missionum Orientalium et Litterae Reipublicae bono e bibilotheca regia in lucem prodit. adjecta est tabula chronologica sinicae monarchiae ab huius exordio ad haec usque tempora.

2 Mencius was translated by Franciscus Noël in 1711 in Prague.

3 On this point, see Lee (1991) 37.

2 OpenAccess. () 2019 Jaewon Ahn, published by De Gruyter. (cc) BY-NC-ND This work is licensed under the Creative Commons Attribution-NonCommercial-NoDerivatives 4.0 License. https://doi.org/10.1515/9783110616804-007 
by Th. Meynard S.J. in Rome in 2011. The praefatio (104 pages), together with TaHio, was translated from the original Latin text and included as an appendix. Unfortunately, this edition and translation is full of mistakes and misinterpretations: the Latin edition also includes serious flaws, including misprints and misreadings of abbreviations. This is certified by manuscript Par. Lat. 6277 (= Par. 6277), which is now preserved at the BNF. Par. 6277 is the original manuscript written by Intorcetta, and was made for the grand purpose of publishing Chinese classics in Europe.

There are three reasons why Intorcetta translated Chum-Yum into Latin: first, to support missions to China, under the motto of 'accommodation policy'; second, he was trying to introduce Chinese ideas of God and religion to European readers; third, and primarily, Chum-Yum was translated to defend Ricci's accomodation policy, which had been strongly criticized by Longobardi and Naverette. Some textual evidence for this comes in Intorcetta's dedication letter and eight commentaries which were totally deleted by Couplet in the Paris publication of Confucius Sinarum in 1687. The real author of the praefatio of Par. 1687 was not Couplet but Intorcetta, although the dedication letter to Louis XIV was written by Couplet. This is what I have to point out before continuing this paper, and with this brief observation, I will start to answer the question of whether Confucius can be regarded as a Sinicus Cicero. My answer to this question is ambivalent, and to clarify the issue, I need to look into the similarities and differences between Confucius and Cicero, making comparisons between the two, as well as between Confucius and Lactantius and between Confucius and Christian Wolff.

\section{Confucius and Cicero}

It is clear that Intorcetta read and understood Chum-Yum through the eyes of Cicero:

This book belongs to Confucius, but was edited by his grandson, named Cu-Su. It deals especially with the middle way or so-called golden rule, that is to be kept constantly, as Cicero would have it, between excess and parsimony in everything. For this reason, it is titled Chum-Yum. Chum signifies the middle, and Yum (meaning ordinary or everyday) refers here to a principle that should be kept constantly. ${ }^{4}$

4 Par. 6277 65. This and the following English translations of the manuscripts and Neolatin texts are of Jaewon Ahn. 
It is useful look further at how to understand 'as Cicero (ut Cicero)' in detail. In this regard, I would point out first of all that Intorcetta's understanding of the Chum-Yum concept is quite similar to Cicero's idea of duty (officium). Intorcetta considered Chum-Yum not to be a mechanical or physical middle term; it is not a middle point between high and low, long and short, or strong and weak. Rather, it is considered to be a universal principle that is recognized in concrete situations and contexts:

p.2. §.1. This true and solid perfection is the very perfection of its own. This means, it is complete in itself. It is accomplished through itself. It cannot be distinguished from itself through other things. The rule is the rule of itself. According to this rule, other things are carried out and directed so that the rule itself should not be driven by other things. §.2. This true and solid principle or perfection is the end and beginning of all things. If this true and solid principle or perfection is absent, nothing will exist. In the same way an act without truth in morals is regarded not as a virtue but as a shade of virtue and a certain surface. For example, if a son obeys but without a true and sincere mind, he is to be regarded as not an obedient one. If a subject serves a king not with fidelity and truth, he cannot be considered to be faithful. On this account, a wise and good man estimates this true and solid perfection as the greatest. ${ }^{5}$

A key concept of Chum-Yum is Xim (誠), which is translated as perfectio. The perfectio here refers to the whole process from the beginning to the end of an action. Chum-Yum is never to be regarded as a middle concept in common understanding. It is interesting to see the similarity between how to distinguish Chum from Yum and how to differentiate Cicero's perfectum officium from medium officium.

Off. I.8: And yet there is still another classification of duties: we distinguish between 'mean' duty, so-called, and 'absolute' duty. Absolute duty we may, I presume, call 'right', for the Greeks call it kathorthôma, while the ordinary duty they call kathêkon. And the meaning of those terms they fix thus: whatever is right they define as 'absolute' duty, but 'mean' duty, they say, is duty for the performance of which an adequate reason may be rendered. ${ }^{6}$

Undoubtedly, Intorcetta borrowed perfectum from Cicero's De officiis. Perfectum officium corresponds to the sive perfectio sive ratio that is rerum omnium finis et principium. The medium officium is parallel to Confucius' regula. Intorcetta interpreted this as follows:

5 Par. 6277 175-176.

6 English translation here and in other quoted passages comes from Miller (1913). 
The rule or way mentioned neither can nor should be absent or separated from human beings at any moment, for it is intrinsic to rational nature. But if at some time it can be absent or separated, it should no longer be a rule or an innate reason of nature from heaven. ${ }^{7}$

We should pay close attention to "an innate reason of nature from heaven" (ratio a coelo naturae insita). This is Intorcetta's translation of 天命之謂性, which means that what is endowed to man from heaven is called a rational nature. ${ }^{8} \mathrm{Cic}$ ero describes ratio like this:

\begin{abstract}
First of all, nature has endowed every species of living creature with the instinct of selfpreservation, of avoiding what seems likely to cause injury to life or limb, and of procuring and providing everything needful for life - food, shelter, and the like. (...) But the most marked difference between man and beast is this: the beast, just as far as it is moved by the senses and with very little perception of past or future, adapts itself to that alone which is present at that moment, while man, because he is endowed with reason, by which he comprehends the chain of consequences, perceives the cause of things, understands the relation of cause to effect and of effect to cause, draws analogies, and connects and associates the present and the future - easily surveys the course of his whole life and makes the necessary preparations for its conduct. ${ }^{9}$
\end{abstract}

More differences than similarities between Confucius and Cicero are to be discovered, if they are compared closely. On this matter, I would rather focus on Intorcetta's remark 'as Cicero' in more detail. His description of the vir perfectus (君子) can be compared to Cicero's vir honestus, who has not only possesses a animus magnitudinis but also a animus moderationis or a animus temperantiae to rule the appetites in his mind. Confucius observed:

Furthermore, this is why a perfect man is always carefully aware of himself and wary even of those who are not seen by his eyes, but just as subtle movements of the mind, and likewise why he fears and trembles at those who are heard by his ears in order not to turn aside from the rule of right reason stamped in himself at any moment, [whenever he has to take action. $]^{10}$

Cicero describes what the vir honestus should be equipped with:

The appetites, moreover, must be made to obey the reins of reason and neither allowed to run ahead of it nor from listlessness or indolence to lag behind; but people should obey calm of soul and be free from every sort of passion. As a result, strength of character

7 Par. 627765.

8 Ibidem.

9 Off. 1.11.

10 Par. 627765. 
and self-control will shine forth in all their lustre. For when appetites overstep their bounds and, galloping away, so to speak, whether in desire or aversion, are not well held in hand by reason, they clearly exceed overleap all bound and measure, for they throw obedience off and leave it behind and refuse to obey the reins of reason, to which they are subject by Nature's laws. And not only minds but bodies as well are disordered by such appetites. We need only to look at the faces of men in a rage or under the influence of some passion or fear or beside themselves with extravagant joy: in every instance their features, voices, motions, attitudes undergo a change. ${ }^{11}$

Confucius' provision "in order not to turn aside from the rule of right reason stamped in himself at any moment" (ne momento quidem deflectat a norma rectae rationis sibi impressa) corresponds to Cicero's "that the appetites should obey the reins of reason" (ut appetitus rationi oboediant). Thus far, it is not strange that Intorcetta compared Confucius with Cicero. The issue of affection will be discussed later, in which a greater difference can be seen between Confucius and Cicero. All in all, the claim of 'as Cicero' may be corroborated by looking at the following remark:

§.3. Confucius declares that the act of five universal rules depends on three cardinal virtues. Their efficacy rests, however, only on solidity and righteousness of mind. There are five universal and obvious rules (or ways) in the world. Those which are put into action are three. The five rules are (1) justice between king and subject, (2) love between parent and children, (3) distinction that should be laid between husband and wife, or faith in marriage, (4) order between brothers, and finally, (5) friendship and social duties that must be observed mutually between friends. These are five general ways and rules of the world. A distinction is made between good and bad, and love is universal to all; fortitude lies in doing good and avoiding and hating the bad; These are three general rules of the world, or cardinal virtues, through which the five rules are to be practiced. These three virtues are practiced through a single one, namely an earnest and true solidity of mind, or righteousness, since it will not be estimated as virtue but rather as vice, if any of the virtues mentioned should go forth from a feigned and deceptive mind. ${ }^{12}$

Intorcetta explained the four cardinal virtues, gin, $l i, y$, chi (仁義禮智) in Confucius Sinarum in terms of Roman virtues: Id est pietas, convenientia, iustitia et prudentia. ${ }^{13}$ This could lead us even to the illusion that we are reading some passages from Cicero's De officiis:

\section{Off. 1.102.}

12 Par. 6277150 - 151.

13 In this regard, it is remarkable that Cicero's humanitas concept is systematically comparable with Mencius' human nature which consists of four sub-principles (四端): probabilitas (是非之 心), misericordia (惻隱之心), liberalitas (辭讓之心) and urbanitas (羞惡之心). To be sure, one should not overlook the fact that there are certain differences between them. 
But all that is morally right rises from some one of four sources; it is concerned either with the full perception and intelligent development of the true; or with the conservation of organized society, with rendering to every man his due, and with the faithful discharge of obligations assumed; or with the greatness and strength of a noble and invincible spirit or with the orderliness and moderation of everything that is said and done, wherein consist temperance and self-control. Although these four are connected and interwoven, still it is in each one considered singly that certain definite kinds of moral duties have their origin; in that category, for instance, which was designated first in our division and in which we place wisdom and prudence, belong the search after truth and its discovery; and this is the peculiar province of that virtue. ${ }^{14}$

This citation makes it clear that Intorcetta's Confucius Sinarum may be compared systematically to e.g. De officiis of Cicero. The Latin version of Kien (謙) can be observed here:

Self-control in everyday life is moderating to the mind so it does not become swollen. It is achieved firstly by regulating oneself, and then then by checking in others whatever exceeds and goes beyond measure owing to arrogance and pride in power and dignity. On the contrary, it supplements and fulfills what is deficient and incomplete not only to oneself but also to others. Just like the needle of a scale it weighs with equity everything of one's own and others. In this manner it assigns each thing to its own with equity. It accommodates and moderates itself to each thing. It wisely raises high someone humble and places someone exalted in safety according to the dignity of each. It levels everything in order. It administrates everything constantly in felicity. ${ }^{15}$

\section{Confucius and Lactantius}

Hegel said: "Cicero gives us De officiis, a book of moral teaching more comprehensive and better than all the books of Confucius."16 I agree with Hegel; however, one should be careful in that, e.g., humanitas in the translated Confucius Sinarum is not identical with Cicero's idea of humanitas, ${ }^{17}$ and that Intorcetta attached the idea of divinitas to Cicero's humanitas; this is supported by Intorcetta's view on the humanitas of Confuicus Sinarum, which is characterized by the fact that it comprises not only human nature itself but also the divinitas in human nature.

14 Off. $1.15-16$.

15 Confucius Sinarum, praefatio. LI.

16 This is quoted from http://www.marxists.org/reference/archive/hegel/. On this see, Kim (1978).

17 On this see Ahn (2010). 
For the philosopher, the sagest, realized only with the light of reason and nature that nothing was so obligatory to ancient people as religion. He applied his doctrine and discipline only to this purpose - that men could regulate their whole life according to the laws and precepts of the holy deity. ${ }^{18}$

It should be pointed out that Intorcetta supplemented eight essays to his translation of Chum-Yum, but these were completely deleted by Couplet during the publication of Par. 1687. The titles of the essays are:

Dig. 1) An Sinae cognoverint et adorarint (coluerint corr. Couplet) spiritus. ('Did the Chinese know and worship spirits?')

Dig. 2) An nomine Xám (上), Tí (帝), prisci intellexerint coelum hoc materiale, an potius supremum coeli imperatorem? ('Did the ancient Chinese understand by the name of Xamti (上 帝) the material heaven or rather the highest ruler of heaven?).

Dig. 3) Tum ratione, tum veterum authoritate plurimisque testimoniis probatur Priscos Sinas non fuisse penitus (om. Couplet) ignaros Supremi Numinis: creberrime item voce coelum ad Numen hoc significandum fuisse usos. ('It can be proved either by rational account or by the authority of ancient people and widespread evidence that the ancient Chinese were not among those who were ignorant of the highest divine will. They frequently used this word for heaven, in order to signify this divine will'.)

Dig. 4) De Sinensium sortibus, auguriis atque prognosticis. ('On fortune telling, auguries and prognostics')

Dig. 5) De Sinarum litteris ('On Chinese letters').

Dig. 6) De Sinensium musica ('On Chinese music').

Dig. 7) Quid senserint prisci Sinae de animorum immortalitate? ('What did the ancient Chinese think about the immortality of souls?')

Dig. 8) An in Sinarum libris mentio quoque fiat praemii poenaeve quae post hanc vitam proborum vel improborum meritis respondeant? ('Is there in Chinese books any mention of reward or penalty to repay the deeds of the good and the bad after death?')

Here is not the place to address the question of why Couplet omitted these precious essays of Intorcetta. However, I point out here that a significant difference between Couplet and Intorcetta is apparent on the divinitas issue. Couplet introduced Confucius to European readers as a mundane philosopher, while Intorcetta considered him to be a religious sage. This is made clear by Couplet's deletion of Intorcetta's opinion of Confucius:

18 Par. 1687, epist. 3. 
Indeed in Europe, where already Socrates and followers of Plato have fallen, and where followers of Seneca and Plutarch have become unrecognized, is it a vain wish that our Chinese Epictetus will restore praise for them? (It would be better that I call him Trismegistus, because he appears to have described his secret thoughts with laconic brevity rather than having expressed them in hieroglyphic notes. $)^{19}$

The sentence highlighted in bold is deleted by Couplet. In this regard, among others I would concentrate on comparing the amor universalis erga omnes that refers to ren (仁) using the natura concept of Cicero.

There is therefore an element that holds the whole world together and preserves it, and this an element possessed of sensation and reason; since every natural object that is not a homogeneous and simple substance but a complex and composite one must contain within it some ruling principle, for example in man the intelligence, in the lower animals something resembling intelligence that is the source of appetition. With trees and plants the ruling principle is believed to be located in the roots. I use the term 'ruling principle' as the equivalent of the Greek hêgemonikon, meaning that part of anything which must and ought to have supremacy in a thing of that sort. Thus it follows that the element which contains the ruling principle of the whole of nature must also be the most excellent of all things and the most deserving of authority and sovereignty over all things. Now we observe that the parts of the world (and nothing exists in all the world which is not a part of the whole world) possess sensation and reason. Therefore it follows that that part which contains the ruling principle of the world must necessarily possess sensation and reason, and there is a more intense and higher form. Hence it follows that the world possess wisdom, and that the element which holds all things in its embrace is pre-eminently and perfectly rational, and therefore that the world is god, and all forces of the world are held together by the divine nature. ${ }^{20}$

Hêgemonikon may be compared with the amor universalis of Confucius, who declares:

§.3. That virtue and universal love, named Gin (仁), is not something external but human itself, or a proper and innate facet of human nature. It orders us to love everyone. To love is human nature. ${ }^{21}$

As cited, however, hêgemonikon is closer to the $L i$ (理) or Taizi (太極) of the NeoConfucians than to the Ren (仁) of Confucius. On this matter, Couplet argued:

19 Par. 6277 IX.

20 Nat. D. 2.29-30. English translation is of Rackham/Warmington (1967).

21 Par. 6277114. 
The fact that they consider the pure material as the prime matter just like our philosophers is confirmed by the argument that they add another name to Taiji, namely $L i$. The word $l i$ in Chinese means just the same as the word ratio in Latin - this is very widely known. They explain Taiji again with this word li for confirming that the essential differences between things come from this single ratio (=li), even arging philosophically that they are building a certain universal entity as a part of a thing. In the same way this universal entity penetrates through particular and individual things. On this basis it is more reasonable to suppose that they truly understand by $l i$ a certain reason or a constitutive and distinctive form, just as they understand primary matter through the word Taiji. ${ }^{22}$

Here we can see clearly just how different from one another Intorcetta and Couplet are, as Intorcetta is opposed to the approach of reading Chum-Yum from the perspective of materialism. Intorcetta read Chum-Yum in this way:

The title and argument of this small book is Chum-Yum, meaning medium or the constancy of the golden mean. Confucius' grandson Cu-Su published the book and added some of his own ideas, but much of the book is lost; it seems to be more a collection of fragments than a fully formed book. Because of this, and because the sublimity of doctrine handed down seems to go beyond human nature, Chinese teachers regard the book as obscure and difficult to understand. Even though it comes second in order, they teach it last in school. Meanwhile (as I said above) it is undoubtedly useful for missionaries. It is excellent, in so far as it shows the light of truth to the natural light cast down by dark vices. It will open the way and offer a leading light for missionaries. ${ }^{23}$

The term "obscure" (subobscurum), is well-known as a description referring to topics in astronomy, metaphysics, and theology. Also, it is a translation of 夫 微之顯 (Chum-Yum ch. 16) meaning 'the uncovering of sacred mystery'. In connection with this, Intorcetta interpreted chapter 16 of Chum-Yum in this way:

Even this subtlety of spirits is concealed, but it is also manifested through the spirits' accomplishments. Even though spirits are concealed in themselves, it is evident that it cannot be hidden actually. It is so manifest. ${ }^{24}$

In a word, Intercetta summarized Chum-Yum as a text of 'true and supreme divinity' (Veri Summique Numinis, sp. 1215). This leads us to the conviction that he read Chum-Yum not only as Cicero but also as a Christian. The question is how he really did read and understand Chum-Yum. Interestingly, he makes one mention of Lactantius:

22 Par. 1687 LVI-LVII.

23 Analecta Monumentorum (1668). sp. 1215-1216.

24 Par. 627784. 
Even though other authorities are at hand for young beginners of these missions and they can attack atheists with these, or else kill them with their swords, (since Chinese people can be strongly refuted only by the Chinese themselves, just as one has to refute Cicero with Cicero, as Lactantius said). It is sufficient here to indicate some passages and to suggest some texts among many where the concept of spirits, and reverence for them, are mentioned clearly and plainly. ${ }^{25}$

It is remarkable that Intorcetta tried to read Chum-Yum with the eyes of Lactantius. For instance, he observed:

As they named Xam-Ti using two words, indeed they taught it as something incorporeal, eternal, immense, infinite, most perfect, clearly the creator and master of heaven and earth. Perhaps just as it could be safely called theos among Athenians and deus among the Romans and by Paul, it can safely be called Xam-Ti among the Chinese, because this name means literally and from its own primary establishment, the highest ruler and master of heaven. If this is so, you may ask, is there any reason for you not to use Tien-Chu, already used far and wide, or Xam-Ti? ${ }^{26}$

We may compare with this the remarks of Lactantius on God:

There is then one God, perfect, eternal, incorruptible, passionless, subject to no circumstance or power; possessing all things, ruling all things, one whom the mind of man cannot assess nor mortal tongue describe. He is too lofty, too great, to be comprehended in thought or word of man. Finally (not to speak of prophets, preachers of the one God), both poets and philosophers testify to one God. Orpheus speaks of a principal God, creator of heaven and earth, of sun and stars, of land and sea. Moreover, our poet Vergil calls the supreme God now spirit, now mind, declaring that mind, as though poured into limbs, sets in motion the body of the whole world; that God passes over seas and lands and through the depths of heaven, and that from Him all creatures derive their life. Even Ovid knew that the world was made by God, whom he calls now the framer, now the architect, of all things. ${ }^{27}$

The comparison makes it clear that Intorcetta's way of interpreting Chum-Yum is very similar to the thought of Lactantius. The concepts of Tien-Chu (天主) and Xam-Ti (上帝) are to be understood as similar to Lactantius' idea of God, and thus Confucius, in Intorcetta's understanding, is to be regarded not only as a Cicero but also as a Christian. Finally, I add philosophus modernus as the third attribute of Confucius. The name of Christian Wolff deserves to be introduced here.

25 Par. 627785.

26 Par. 6277106.

27 Epit. Div. inst. divinarum 1.3. English translation comes from Blakeney (1950). 


\section{Confucius and Wolff}

Christian Wolff was a very significant Sinophile. It is noteworthy to see how he read Confucius Sinarum. Wolff mentions Confucius explicitly:

(39) Confucius himself considers harmony with the rational nature of actions to be the norm. He declares at f. 40 in the book Chum-Yum, the second book of Chinese science, that which is modified reason is the law, from which every action is to be derived, and it is also proper to rationality; the discipline of virtue consists of this, such that we and our actions should be conducted according to it. ${ }^{28}$

In this regard, it should be pointed out that Wolff's statement is essentially identical to that of Confucius Sinarum. This is made evident in the following comparison:

\begin{tabular}{|c|c|}
\hline Confucius Sinarum & Wolff \\
\hline $\begin{array}{l}\text { Id quod a caelo est homini inditum dicitur } \\
\text { natura rationalis: quod huic conformatur na- } \\
\text { tura et eam consequitur, dicitur regula, seu } \\
\text { consentaneum rationi, restaurare quoad } \\
\text { exercitium hanc regulam se suaque per eam } \\
\text { moderando, dicitur institutio, seu disciplina } \\
\text { virtutum. }\end{array}$ & $\begin{array}{l}\text { quod naturae rationali conformatur, illud esse } \\
\text { regulam, juxta quam actiones dirigendae, } \\
\text { idem esse rationi consentaneum, et virtutis } \\
\text { disciplinam in eo consistere, ut nos et nostra } \\
\text { per eam moderemur. }{ }^{30}\end{array}$ \\
\hline
\end{tabular}

As we see here, Wolff used almost the same words as Confucius. Wolff's words rationi consentaneum recall Confucius' regula, seu consentaneum rationi. Wolff appropriated the remark consentaneum passionum, or cum ipsa ratione concentus in Confucius Sinarum to harmonia animae ac corporis in Psychologia Rationalis. He defines natura rationalis in Confucius Sinarum as objective moral discipline. ${ }^{31}$ The reason why he tried to introduce Confucius was to make it clear that moral principles and political discipline are grounded in natura humana, not in gratia divina. On this basis, Wolff began to establish Psychologia rationalis. What is emphasized is that the rules of morality or ethics should serve for appetites or desires. To be sure, this is now a much-popularized view, but it was not such a simple matter at the time when Wolff lived, because human desires were controlled

28 Oratio de Sinarum philosophia practica 130.

29 Par. 627765.

30 Oratio de Sinarum philosophia practica 130.

31 Oratio de Sinarum philosophia practica 128: Actionum honestatem et turpitudinem intrinsecam, quam moralitatem objectivam vocarunt. 
and regulated by the churches. According to Wolff, controlling one's desires is not a matter for the Church, but a matter of 'sibi conscius'. In this point, it should not be overlooked that Wolff did not aim at designing a theory of psychology in the modern sense. Rather, he strove to provide a moral principle that was rooted in natura humana. Consequently, Wolff's psychologia is basically parallel to Simhak (心學). Let us listen to Wolff's own voice:

\begin{abstract}
Psychologia Rationalis embodies a sublime philosophy, which leads to a deeper cognition of our mind. A sublime science of sublime things is properly required for sublime natures. This science nourishes the spirit with its delight. Even though self-knowledge was sometimes recommended by saints in past ages, it should be recommended particularly to know the innermost and noblest part of our mind, because from this a certain light of acquaintance not only of universal nature but also of the very originator himself, of the most wise and mighty deity, shines brightly in an unexpected way. In addition, this knowledge provides protection to each single virtue; this is what nobody knows unless it is experienced. What indeed is more delightful, what is more desirable than to see inwardly the nature of things, that admirable function which the supreme Master brought about for the purpose of acknowledging himself and to look upon the Master himself in it just as in the mirror? ${ }^{32}$
\end{abstract}

The 'self-cognition' (cognitio sui) is identified in the following passage from Chum-Yum:

What belongs to movements of mind is almost like those things which are not visible, because they are hidden and known only to one's own mind. They are in the same way like what is not manifest, because they are exceedingly subtle and quite minuscule. Therefore, the vir perfectus watches so carefully over his heart in secret and is very cautious about those innermost things which only he himself sees. This leads us to the fact that, even though the inner and secret parts of our heart are invisible and hidden from others, they are nevertheless evident to our own mind. ${ }^{33}$

The term self-cognition (sibi conscius) is noteworthy in that it later became used as a vital concept in modern psychology. Textual evidence is found in the following:

Psychologia Rationalis is examined in a scientific way [and from a scientific perspective], and through this way, what is made known about the human mind in dubious certainty

32 Psychologia rationalis, Praefatio 2.

33 Par. 627766. 
of experience is explained through the essence and nature of mind, and is published to be useful for cognition of our innermost nature and its performer. ${ }^{34}$

The remark "for cognition of our innermost nature and its performer" (ad intimiorem naturae ejusque autoris cognitionem) refers to a specific form of self-cognition (sibi conscius). The Latin word conscius is used in the sense of Gewissen. Sibi conscius here is the same as cognitio sui. On this point caution is required, because Wolff's idea of cognitio sui is closer to the notion of cordis sui in Confucius Sinarum, in which was highlighted the importance of practice in real life. This is evident in the passage 'the vir perfectus watches carefully over his heart in secret and is very cautious for inner things which only he himself sees innermost' (ideoque perfectus vir tam sollicite invigilat cordis sui secreto et cautus est in internis quae solus ipse intuetur). According to Dyck (2011) 2, Wolff's most important ideas are based on the philosophy of Leibnitz, especially regarding the question of the discovery of cognition (Entdeckung des Bewusstsein). Testimonies provided by Dyck for this are chapters 208 and 214 of Philosophical Essays. To be sure, Leibniz was a very important philosopher for Wolff, but to argue further, Leibniz's Nouveaux essais sur l'entendement humain was published in 1765, even though it had been completed in 1704. Wolff died in 1754, and so the question can be raised of whether Wolff indeed read this book. He might have read a manuscript, or he might have known about it through letters. As seen above, however, one should be cautious about whether Wolff's philosophy was basically founded on that of Leibniz. All in all, the remark 'the highest master' (artifex summus) reminds us of the vir perfectus in Scientia Sinica. In addition to this, the word speculum (mirror) is noteworthy, because it echoes the 'the cleanest mirror' (limpidissimum speculum) in the Scientiae Sinicae Liber Primus (Ta-hio).

The pinnacle of learning for great men is to polish or refine the rational nature bestowed on them from heaven in order that this can restore them to a primitive stage of clarity by removing the stains of crooked desires, just like the cleanest mirror. Next, it is to renew or to revive people through their own example and exhortation. Finally, it is to stand firmly or to persist in the supreme good. ${ }^{35}$

Wolff also uses the metaphor of a mirror in German Metaphysics (1719) 729:

34 Psychologia rationalis, praefatio 2: Psychologia Rationalis, methodo scientifica pertractata, qua ea, quae de Anima humana in dubia experientiae fide innotescunt, per essentiam et naturam animae explicantur, ad intimiorem naturae ejusque autoris cognitionem profutura proponuntur. 35 Par. 6277 1-2. 
I am conscious that I see the mirror not merely when I distinguish the various parts that I see in it from another, but rather when I also represent to myself the distinction of the mirror from other things that I either see at the same time or saw shortly before.

As we saw in the above, however, it is difficult to find Wolff's self-concept in Confucius Sinarum. Nevertheless, the mirror idea of Confucius Sinarum is very similar to that of Wolff. To be sure, there is also a certain difference between Wolff and Confucius. Wolff's mirror is characterized by the fact that it functions as a cognitive mechanism, while that of Confucius is not a simple metaphor but a medium which embeds 'natural reason' (natura rationalis, 明德). What must be pointed out is that Wolff's Psychologia is a systematic and analytic theory which focuses on describing and categorizing the function and structure of mind or soul, clearly from a Western perspective. In a word, however, Confucius does not present such a theory. According to Dyck, anyway, Wolff's psychologia was a kind of Vorlage for Kant's critical philosophy. On this point, it is necessary to emphasize that one of the main reasons for his writing Psychologia was to establish some important moral-political values which were independent of the Church.

Nothing so sublime is given [to us] by Nature. This is what you need not to enlarge, to amplify, or to complete intentionally, so that you publish documents on those virtues still in the early stage of growth. These documents carry all the points needed for governing the country wisely and successfully. In particular, even the love of [our] ancestors for the profound sciences, through which secrets of Nature and scholarship are revealed, promoted such deep-bottomed roots in minds in order that they would be under an obligation to promise confidently that they will claim [our] minds to cultivate themselves, however many they are. ${ }^{36}$

Interestingly, Wolff clarifies the main aim of his text as demonstrating moral principles based in the human mind. It may be difficult to say that his aim arrived at its own telos, at least with his Psychologia project - it was Immanuel Kant who accomplished that; to show this, it is sufficient just to mention the $\mathrm{Ka}$ tegorischer Imperativ. But Kant does not call the moral principles external powers or conditions like religion; he does suggest seeking for reason and rationality in one's inner court. So far, it may not be by chance that one can see the similarities commonly found between Kant and Confucius, because the pure reason of Kant functions in a similar way to the natural reason of Confucius. At least, pure reason does not depend on religion. Rational nature also functions per se without any external condition. The rational nature of Confucius is distinct from Kant's

36 Psychologia rationalis, praefatio 2. 
pure reason in that it was seeded from heaven and therefore was not a pure and simple thing. Thus, it is difficult to say that the vir perfectus has free will and autonomy (voluntas libera et autonomia), which are essential characteristics of Kantian philosophy, because he should always observe the laws of heaven (天 命) assiduously. This may be a reason why Jesuit missionaries make a great effort to find similarities to Christianity in Confucius. On this issue, however, it is worth drawing a comparison between Kant's idea of autonomy and 'self-satisfying' (sibi satisfaciens, 壃獨) in Confucius Sinarum, ${ }^{37}$ since one can ask the question concerning free will (voluntas libera) in the moment of 'self-satisfying' (sibi satisfaciens), even though it may be a problem of translation in this case. The Latin word satis (壃, so translated by Costa or by Intorcetta) is closely related to the idea of 'will' (voluntas), because the Latin word satis-facere refers to a decision based on voluntas libera. Up to this point, all in all, rational nature differs from pure reason on both points, pure rationality and free will. As for the question of religion, however, one can find some structural similarity between Confucius Sinarum and Die Religion innerhalb der Grenzen der bloßen Vernunft. If this is the case, discussion is open, even though they are evidently different from one another. Especially on this issue, it is good to make a comparison between Kant and Cheung Dasan (丁茶山), because Kant might have read or at least heard about Confucius Sinarum, while Dasan had also read some important Chinese translations of Aristotle and the Ancient and New Testament.

\section{Conclusion}

To conclude, three stylistical colors that cannot be grasped in the original Chinese text are observed in Intorcetta's translation of Chum-Yum. One is color Ciceronis, another is color Lactantii and the third is color philosophi moderni ut Wollffiani. All in all, the issue of color leads to the question of how to read the Latin Chum-Yum. On a related issue, Zhang Si-Ping (張西平), a leading scholar in China, argues thus. First, Confucius Sinarum is to be read from the perspective of Christianity. Second, Confucius Sinarum is an answer to ritual discussions of the $17^{\text {th }}$ century. Third, it is a text which takes a critical position, particularly on Neo-Confucianism. Zhang concludes that Confucius Sinarum is a product that resulted from a misreading and misunderstanding of Chinese classical texts, but that it still provides us with a significant contribution for studying the interrelated history of China and Europe. Grosso modo, I agree with Zhang's arguments.

37 Cf. Scientiae Sinicae, §2. f. 6. 2: Huiusmodi dicitur sibi satisfaciens, seu se ipso contentus. 
There are, however, three points on which I do not agree with him. First, while Zhang believes that Jesuit missionaries tried to read the original Chinese texts of Confucius with Christian eyes, Confucius Sinarum is full of termini technici from Cicero and Stoic philosophy. Second, Zhang maintains that one has to be cautious in the interpretation of Confucius Sinarum because it is a 'metamorphic' (變異) text. I believe that it would be better to ask how to approach this metamorphic text. For this purpose, while Zhang suggests that readers should have some basic understanding of Christianity, I would add that some profound understanding of Western, and in particular, Hellenistic philosophy, is needed because the problems of metamorphosis in Confucius Sinarum mostly result from the so-called abusio problem that arose in borrowing, e.g., Cicero's terms. As for Zhang's estimation of Confucius Sinarum, at the end of the day, I am not sure whether it is a product of misreading because, according to a close reading of the original Latin text, Confucius Sinarum is a metamorphosis text in the Ovidian sense as well as a hybrid text because it allows at least three different modes of interpretation. In this regard, Intorcetta certified explicitly that Confucius Sinarum was a metamorphic text or at least a kind of compound text of both Eastern and Western philosophy, in the remark nostrates scientias, ad quas nos iam suam ipsorum philosophiam adjunxissemus. An example of this is Wolff's term psychologia, which might be influenced by the natura concept in Scientiae Sinicae Liber Secundus, since Wolff's concept psychologia is structurally compared with the natura concept in Scientiae Sinicae Liber Secundus (中庸). We should point out that Wolff's psychologia is an idea which cannot be understood from a viewpoint of modern psychology. In my view, it is a concept which stands nearer to the natura concept of Scientiae Sinicae Liber Secundus. Anyway, the term did not come into popular use until Wolff used it in his Psychologia Empirica (1732) and Psychologia Rationalis (1734). In this regard, I would remark that the natura (性) concept in Scientiae Sinicae Liber Secundus is neither identical with the anima concept of Aristotle, nor with the understanding of anima in scholastic tradition. It is, in a way, a 'hybrid' concept: because, on the one hand, the term natura in the translation can be compared to the term psychologia, while on the other, the two are not completely identical. From this it is certain that the term natura in the translation is still unique in western philosophy, and Confucius Sinarum is, in my view, a 'crossbreed' text. Finally, I would ask once again, is Confucius a Sinicus Cicero? The answer is still uncertain. However, it is certain that he deserves still to be discussed in global perspective, because the Confucius in Confucius Sinarum spoke about the human condition in general, not only about homo sinensis from a national perspective. In my view, Confucius Latinus at least is to be considered not only a philosophus Sinensis but also a philosophus universalis. In the present day, some thinkers like Pierre Hadot 
and Jeremy Rifkin have suggested seeking unity between mind and body. Scholars like ourselves today try to find a new way of human understanding through classical texts that remain important for sustaining and building civilizations. Unpopular though it may be, I think Confucius Sinarum is a good candidate for the role of a bridge between East and West. Who knows in the end what kind of a new philosophy will be born from a free reading of Confucius Sinarum in this global age? 
